\title{
Penicillin Acylase Production By Micrococcus luteus and Staphylococcus \\ spp. Isolated from Soda Lake.
}

\author{
Vivek Tembhurkar ${ }^{1}$, Anuradha Patil ${ }^{2}$, Chetan Chaudhari ${ }^{3}$, Manjiree Kulkarni ${ }^{3}$, \\ Sanjay Harke ${ }^{3}$ \\ ${ }^{I}$ Dept. of Microbiology, Arts, Science and Commerce College, Badnapur(MS), India \\ ${ }^{2}$ Quality Control, Vaishali Aromatics Pvt. Ltd., Aurangabad, India. \\ ${ }^{3}$ Dept. of Biotechnology, MGM's Institute of Biosciences and Technology, Aurangabad, India.
}

\begin{abstract}
Two strains of $M$. luteus and a Staphylococcus spp capable of producing penicillin acylse were isolated from lonar lake water. Optimum penicillin acylse production time for M. luteus was $72 \mathrm{hrs}$ and $48 \mathrm{hrs}$ for Staphyloccus spp. Elevated temperature $\left(40\right.$ to $\left.50^{\circ} \mathrm{C}\right)$ better suited penicillin acylse production. Glucose and sucrose stimulated penicillin acylse production by M. luteus and Staphyloccus spp respectively. Penicillin acylse from M. luteus worked optimally at neutral to slightly alkaline $\mathrm{pH}$ and within 60 to $80^{\circ} \mathrm{C}$. Staphylococcus spp. worked better at $\mathrm{pH}$ 6. Penicillin acylse was more active against ampicillin.
\end{abstract}

Keywords: Ampicillin, Lonar lake, M. luteus, Penicillin acylase, Staphylococcus.

\section{INTRODUCTION}

Enzymatic method for large scale production of 6-aminopenicillanic acid employs penicillin acylase or penicillin amidohydrolase (EC 3.5.1.11) thus is one of the most important enzyme applied in the pharmaceutical industry [1]. 6aminopenicillanic acid is starting material for synthesis of semisynthetic penicillin [2]. Many genera of molds, yeast and bacteria produce penicillin acylases. Among them, enzyme produced by E. coli is the most well-characterized and common one for industrial application. E. coli is known to produce an intracellular penicillin acylase that can be induced by phenylacetic acid [3].

Due to high industrial importance of penicillin acylase, numerous efforts have been made towards screening for strains overproducing this enzyme [4]. Penicillin acylase is, in general, produced in fermentative process and is obtained from either mutated or natural variant strains [5]. The catalytically active enzyme derived from E. coli is in the form of $\alpha, \beta$ heterodimer localized in periplasmic space of cell [6]. Penicillin acylase has also been used for synthesis of amoxicillin [7].

The E. coli penicillin acylase being intracellular is quite difficult to purify. Even if whole cell are used for catalysis it would pose substrate/product diffusion problem thereby putting break on speed of reaction. The present communication describes our findings on penicillin acylase producers M. luteus and Staphylococcus spp. isolated from Lonar Lake, a soda lake (In Buldhana district (MS), India which is an alkaline habitat. Very few reports of penicillin acylase of these two are available. Thus we have also optimized few production parameters and reaction conditions.

\section{MATERIALS AND METHODS}

2.1. Isolation of Penicillin $\mathbf{G}$ resistant bacteria: For enrichment $1.0 \mathrm{~mL}$ lonar lake water sample was added to nutrient broth $(\mathrm{g} / \mathrm{L}$, Beef extract 3; Bacteriological peptone 5; $\mathrm{NaCl} 5)$ tubes with increasing $\mathrm{pH}(7,8,9$ and 10). The broth was supplemented with $0.1 \%$ benzathine penicillin. For isolation loop full enriched sample was streaked on nutrient agar (Nutrient broth $+2 \%$ agar agar) + benzylpenicillin of respective $\mathrm{pH}$.

2.2. Screening of Penicillin Acylase Producers: Three isolates LL1, LL2 and LL3 were grown for 24hrs on nutrient medium composed of g/L, $\mathrm{MgSO}_{4} 0.2 ; \mathrm{KH}_{2} \mathrm{PO}_{4} 3.0 ; \mathrm{K}_{2} \mathrm{HPO}_{4}$ 7.0; Yeast extract 5.0; Peptone 20.0; Benzylpenicillin 10; Agar agar 20. Cultures were then screened for PAG activity by acidimetric method (8). The test reagent was composed of Penicillin G, $600 \mathrm{mg}+$ Phenol red $(0.5 \%), 0.5 \mathrm{~mL}+$ Sterile distilled water, $4.5 \mathrm{~mL}$. The test reagent was adjusted to $\mathrm{pH} 8.5$ with $1.0 \mathrm{M} \mathrm{NaOH}$ giving violet color to the solution. Three drops of freshly prepared reagent was added to $0.5 \mathrm{~mL}$ cell suspension of test cultures. The cultures positive from penicillin acylase activity were subjected to biochemical characterization for identification [9].

2.3. Penicillin Acylase Assay: Penicillin acylase assay was done by p-Di-Methyl Amino Benzyldehyde (PDAB) method [10]. The PDAB reagent composed of PDAB 1.5g, Acetic acid $100 \mathrm{~mL}$, Methanol $60 \mathrm{~mL}$, and water $40 \mathrm{~mL}$. Reaction mixture composed of Cell suspension, $1 \mathrm{~mL}+0.5 \%$ Penicillin $\mathrm{G}$ in $0.1 \mathrm{M}$ Phosphate buffer, $5 \mathrm{~mL}$. After incubation at $40^{\circ} \mathrm{C}$ for $40 \mathrm{~min}$ 
$1.5 \mathrm{~mL}$ PDAB reagent was added. The 6-APA produced was measured spectrophotometrically at $415 \mathrm{~nm}$. One unit of penicillin acylase was taken as amount of enzyme required to liberate $1 \mu \mathrm{Mol}$ of 6 -amino penicillanic acid per minute under assay conditions.

2.4. Nature of Penicillin Acylase: For determination of nature of enzyme (extracellular/ intracellular) penicillin acylase producer organism was grown in presence of Penicillin G. Cells were separated from rest of medium by centrifugation and penicillin acylase activity in pelleted cells and cell free supernatant was determined. .

2.5. Optimization of Growth Conditions for Penicillin Acylase Production: For time course and temperature optimization the production media used composed of $\mathrm{g} / \mathrm{L}$, Beef extract 3.0; Bacteriological peptone 5.0; $\mathrm{NaCl}$ 5.0; Benzylpenicillin 10; $\mathrm{pH}$ 7. For time course optimization the $5 \%$ inoculums of test organism was inoculated in production medium. Penicillin acylase activity was determined after every $24 \mathrm{hrs}$ for 4 days. For temperature optimization inoculated production medium was incubated at different temperatures $\left(20,30,40,50\right.$ and $\left.60^{\circ} \mathrm{C}\right)$. Effect of glucose, lactose and sucrose on penicillin acylase production was studied. For this the production media was supplemented with $0.2 \%$ test sugar.

2.6. Characterization of Penicillin Acylase: Effect of temperature on penicillin acylase activity in range $20,30, \ldots 80^{\circ} \mathrm{C}$ was determined. To study effect of $\mathrm{pH}$ on penicillin activity the substrate solution was prepared in buffers with different $\mathrm{pH}(4,5$, $6, \ldots$ 10). To check specificity penicillin acylase was reacted with different beta lactum antibiotics - ampicillin, piperacillin, benzathine penicillin, Benzyl penicillin.

\section{RESULT}

Three isolates were obtained from plate with $\mathrm{pH}$ 7, 9 and 10, no growth was observed on agar plates of $\mathrm{pH} 8$. Isolates were given codes as LL1, LL2 and LL3. In acidimetric test we found that all three cultures changed the color of phenol red from violet to deep red (Fig: 1) which persisted for more than 48hrs this confirms all cultures are penicillin acylase positive and the penicillin resistance is not just because of $\beta$-lactamase. Morphological appearance and biochemical activities of three bacteria are enlisted in Table 1. The results were compared with Bergey's manual of Determinative Bacteriology. From this it can be concluded that LL1 \& LL3 are strains of Micrococcus luteus and LL2 is Staphylococcus spp. Two M. luteus were distinguished as M. luteus I and M. luteus II according to $\mathrm{pH}$ in which it was grown 7 and 10 respectively. Penicillin acylase activity of both strains of M. luteus and Staphyloccus spp. were showing almost double in supernatant than in pellet (Table 2). This shows that the enzyme is largely extracellular.

The penicillin acylase production conditions for all cultures were optimized. Penicillin acylase production by both $M$. luteus strains reached maximum on $3^{\text {rd }}$ day of incubation whereas with Staphyloccus spp. the peak production was on $2^{\text {nd }}$ day (Table 3). In case of optimum production temperature we found M. luteus I produced penicillin acylase at higher level when grown at $40^{\circ} \mathrm{C}$ and other two did same at $50^{\circ} \mathrm{C}$ (Table 4). Production medium when supplemented with glucose penicillin acylase production by $M$. luteus was stimulated, whereas sucrose stimulated penicillin acylase production by Staphylococcus spp (Table 5).

The penicillin acylase temperature optimum for M. luteus I and Staphylococcus spp. was found to be at $80{ }^{\circ} \mathrm{C}$ and $M$. luteus II was working best at $60{ }^{\circ} \mathrm{C}$ (Figure 2). Pencillin acylase of M. luteus worked better in slightly alkaline pH whereas penicillin acylase of Staphylococcus spp. was working best at pH 6 (Figure 3). Substrate specificity of penicillin acylase against few other beta lactum antibiotics was checked. The results are presented in histogram (Figure 4). All three penicillin acylase worked with almost similar efficiency against Penicillin G, Piperacillin and Benzathine penicillin. Whereas all three much more rapidly deacylated ampicillin. 


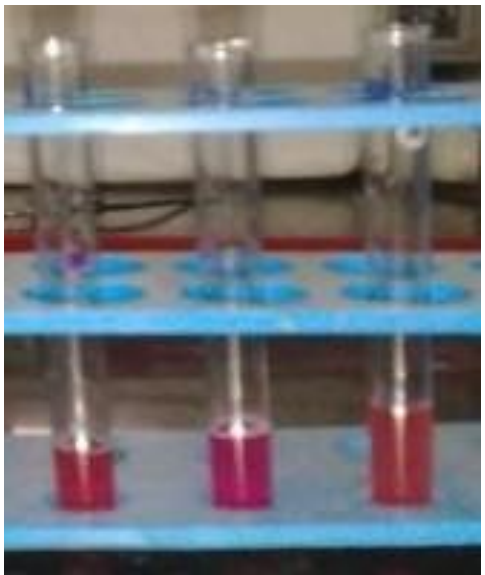

Figure 1: Screening of penicillin acylase producers.

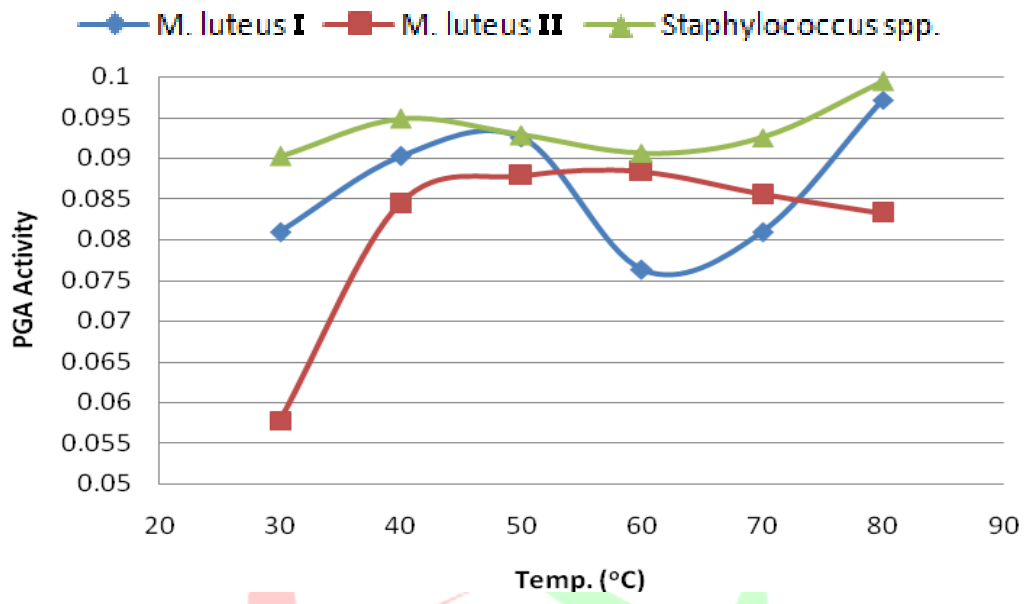

Figure 2: Effect of temperature on penicillin acylase activity.

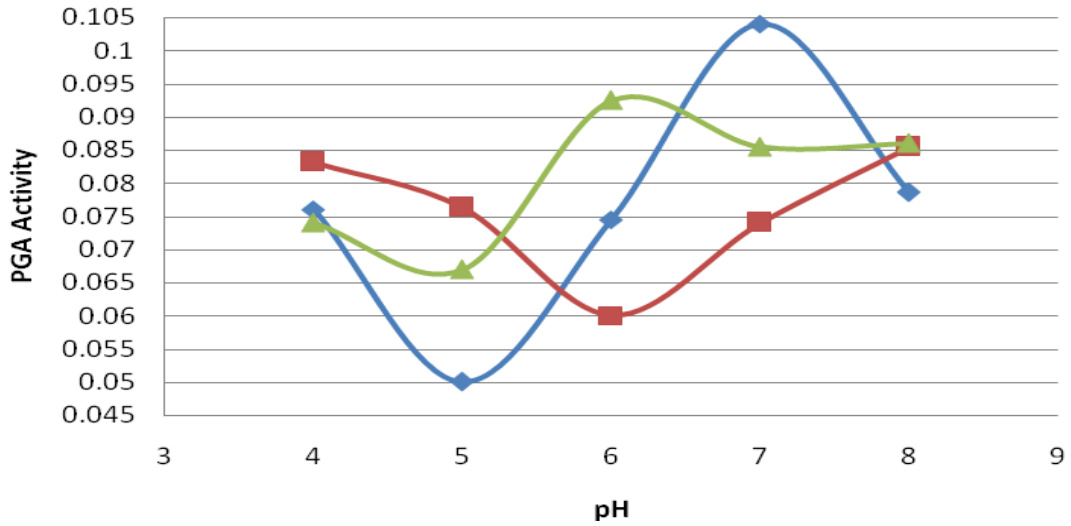

Figure 3: Effect of $\mathrm{pH}$ on penicillin acylase activity. 


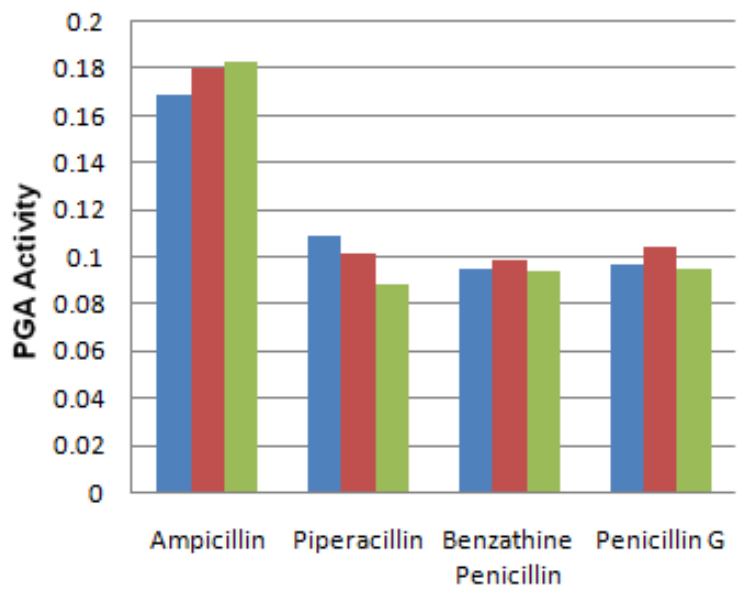

Figure 4: Substrate specificity of penicillin acylase.

Table 1: Morphological appearance and Biochemical activities of penicillin acylase producers.

\begin{tabular}{|l|l|l|l|}
\hline Characters & LL1 & LL2 & LL3 \\
\hline Pigmentation & Yellow & Off white & Yellow \\
\hline Shape of cells & Cocci & Cocci & Cocci \\
\hline Arrangement & Chains & Clusters & Chains \\
\hline Gram Nature & +ve & $+\mathrm{ve}$ & +ve \\
\hline Motility & $-\mathrm{ve}$ & $-\mathrm{ve}$ & -ve \\
\hline Indole Production & $-\mathrm{ve}$ & $-\mathrm{ve}$ & -ve \\
\hline Methyl red & $-\mathrm{ve}$ & $-\mathrm{ve}$ & -ve \\
\hline Voges Proskeur Test & $-\mathrm{ve}$ & $-\mathrm{ve}$ & $-\mathrm{ve}$ \\
\hline Citrate Utilization & $-\mathrm{ve}$ & $-\mathrm{ve}$ & -ve \\
\hline Glucose Fermentation & $-\mathrm{ve}$ & $-\mathrm{ve}$ & $-\mathrm{ve}$ \\
\hline Sucrose Fermentation & $-\mathrm{ve}$ & $+\mathrm{ve}$ & $+\mathrm{ve}$ \\
\hline Fructose Fermentation & $-\mathrm{ve}$ & $-\mathrm{ve}$ & $-\mathrm{ve}$ \\
\hline Lactose Fermentation & $-\mathrm{ve}$ & $-\mathrm{ve}$ & $-\mathrm{ve}$ \\
\hline Catalase Test & $+\mathrm{ve}$ & $+\mathrm{ve}$ & $+\mathrm{ve}$ \\
\hline
\end{tabular}

Table 2: Determination of nature of penicillin acylase.

\begin{tabular}{|l|l|l|}
\hline Culture & PGA activity in Supernatant & PGA activity in Pellet \\
\hline M. luteus I & 0.0832 & 0.0346 \\
\hline Staphyloccus spp. & 0.0879 & 0.0416 \\
\hline M. luteus II & 0.0693 & 0.0300 \\
\hline
\end{tabular}

Table 3: Time course of PGA production.

\begin{tabular}{|l|l|l|l|}
\hline Incubation Time (hr) & M. luteus I & M. luteus II & Staphylococcus Spp. \\
\hline $\mathbf{2 4}$ & 0.064 & 0.065 & 0.076 \\
\hline $\mathbf{4 8}$ & 0.074 & 0.0925 & 0.0948 \\
\hline $\mathbf{7 2}$ & 0.1087 & 0.1040 & 0.0855 \\
\hline $\mathbf{9 6}$ & 0.1017 & 0.0786 & 0.0902 \\
\hline
\end{tabular}


Table 4: Temperature optimization.

\begin{tabular}{|l|l|l|l|}
\hline Temperature $\left({ }^{\circ} \mathbf{C}\right)$ & M. luteus I & M. luteus II & Staphylococcus spp. \\
\hline 20 & 0.0740 & 0.0601 & 0.0751 \\
\hline 30 & 0.0763 & 0.0717 & 0.0717 \\
\hline 40 & 0.0832 & 0.0693 & 0.0879 \\
\hline 50 & 0.0602 & 0.0751 & 0.0902 \\
\hline 60 & 0.0624 & 0.0763 & 0.0855 \\
\hline
\end{tabular}

Table 5: Effect of Carbon source.

\begin{tabular}{|l|l|l|l|}
\hline Carbon Source & M. luteus I & M. luteus II & Staphylococcus spp. \\
\hline Glucose & 0.0185 & 0.578 & 0.0092 \\
\hline Sucrose & 0.0138 & 0.037 & 0.0393 \\
\hline Lactose & 0.010 & 0.0370 & 0.0254 \\
\hline
\end{tabular}

\section{DISCUSSION}

In present study M. luteus and Staphylococcus spp. extracellular penicillin acylase producers were isolated from lonar lake water. Few characteristics of enzymes like optimum temperature, $\mathrm{pH}$, substrate specificity was determined and few production parameters were optimized. Nam and Ryu, 1979 reported that penicillin acylase of M. luteus showed optimum activity at $36^{\circ} \mathrm{C}$ and $7.5 \mathrm{pH}$. Our findings are agree with the this $\mathrm{pH}$ optima but could tolerate higher temperature. The also reported the enzyme was active against penicillin V and ampicillin (11). Sedigheh Javadpour et al. 2002, characterized penicillin acylase of $E$. coli and the found that the $\mathrm{pH}$ and temperature optimum was 8 and $60^{\circ} \mathrm{C}(1)$. According to Hesham et al. 2009, penicillin acylase production by $E$. coli reaches maximum after $19 \mathrm{hrs}$ of incubation remained stable up to 24hrs after which it declined. Thus our isolates were slower compared to E. coli (6). Szentirmai, 1964, proposed the inhibitory effect of carbohydrates on penicillin acylse production when added to medium at higher concentration (12).

\section{CONCLUSION}

M. luteus and Staphylococcus spp. used here produce extracellular penicillin acylse. Production of enzyme is better at elevated temperature. Enzyme of both tolerated higher temperature but pH should be near neutrality. Presence of glucose and sucrose at small concentration stimulated enzyme production by M. luteus and Staphylococcus spp respectively. Penicillin acylase from both these bacteria has broad substrate specificity even Penicillin G was added to production medium as inducer for enzyme production. And surprisingly the enzyme was more active on ampicillin rather than other beta lactum antibiotics tested.

\section{REFERENCES}

[1] S. Javadpour, D. Norouzian, A. Akbarzadeh, S. Mirdamadi and B. Farahmand, Isolation of a Penicillin Acylase Producing E.coli and Kinetic Characterization of the Whole Cell Enzyme Activity, Iranian Biomedical Journal, 6(2): 2002, 93-96.

[2] G. Walsh and D. Headon, Protein biotechnology (John Wiley \& Sons, England, 1994) 342-345.

[3] C.P. Chou, J.H. Tseng, M.I. Lin, H.K. Lin and C.C. Yu, Manipulation of carbon assimilation with respect to expression of the pac gene for improving the production of penicillin acylase in Escherichia coli, Journal of Biotechnology, 69: 1999, 27-38.

[4] H. Azimi, S. Farajnia, R. Moadab, N. Saeedi, H. Feizi, Biological Screening and identification of penicillin $\mathrm{G}$ acylase producing E. coli and optimization of production condition, The Quarterly Journal of Biological Sciences, 3(2): 2012, 27-35

[5] L. José, H. Martinez, A. Iliyná, L. D. Malfavon, C. O. Sánchez and M. J. C. Dustet, Partial characterization of penicillin acylase from fungi Aspergillus fumigates and Mucor gryseocianum, Moscow University Chemistry Bulletin, 44(1): 2003, 53-56.

[6] H. A. El Enshasy, M. S. Mohy El Din, M. El Sayed, S. El Sayed, B. M. Haroun and E. A. Hassan, Optimizaation and scaling up of penicillin acylase production by Escherichia coli, World Applied Sciences Journal, 6(10): 2009, 1348-1358.

[7] I. Alemzadeh, G. Borghei, L. Vafi and R. Roostaazad, Enzymatic synthesis of amoxicillin with immobilized penicillin G acylase, Transactions C: Chemistry and Chemical Engineering, 17(1): 2010, 106113.

[8] V. Meevootisom, P. Somsuk, R. Prachaktam and T. W. Flegel, Simple screening method for isolation of penicillin acylase producing bacteria, Applied and Environmental Microbiology, 46(5): 1983, 1227-1229. 
[9] J. P. Harley and L. M. Prescott, Laboratory Exercises in Microbiology (The McGraw Hill Companies) 2002.

[10] W.S. Adriano, E.H.C. Filho, J.A. Silva, R.L.C. Giordano and L.R.B. Gonçalves, Stabilization of penicillin $\mathrm{G}$ acylase by immobilization on glutaraldehyde activated chitosan, Brazilian Journal of Chemical Engineering, 22(40): 2005, 529 - 538.

[11] D.H. Nam and D.D.Y. Ryu, Biochemical properties of penicillin amidohydrolase from Micrococcus luteus, Applied and Environmental Microbiology, 38(1): 1979, 35-38.

[12] A. Szentirmai, Production of penicillin acylase, Applied Microbiology, 12(3): 1964, 185-187. 